\title{
PENGEMBANGAN MODEL PERMAINAN RINTANGAN (HANDICAP GAMES) UNTUK LATIHAN KEBUGARAN JASMANI ANAK USIA 10-12 TAHUN
}

\author{
DEVELOPING A HANDICAP GAMES MODEL \\ FOR PRACTICING THE PHYSICAL FITNESS OF 10-12 YEARS OLD CHILDREN
}

\author{
Tonang Juniarta, Siswantoyo \\ SMP Negeri 2 Klaten, Universitas Negeri Yogyakarta \\ alyajuniarta@yahoo.com,yoyok_uny@yahoo.com
}

\begin{abstract}
Abstrak
Penelitian ini bertujuan untuk menghasilkan model permainan rintangan untuk latihan kebugaran jasmani anak usia 10-12 tahun. Jenis penelitian ini adalah penelitian pengembangan yang mengadaptasi model dari Borg dan Gall (1983), dengan tujuh tahap yaitu: (1) pengumpulan informasi, (2) analisis kebutuhan, (3) produk awal, (4) validiasi ahli dan revisi, dan (5) uji coba skala kecil dan revisi, (6) uji coba skala besar, dan (7) produk akhir. Uji coba skala kecil dilakukan terhadap 40 anak di SD Negeri 1 Klaten. Uji coba skala besar dilakukan terhadap 120 di SD Negeri 2 Klaten dan SD Negeri 4 Klaten. Instrumen pengumpulan: (1) pedoman wawancara, (2) skala nilai, (3) pedoman observasi permainan, (4) pedoman observasi keefektifan permainan. Teknik analisis data adalah deskritif kualitatif dan kuantitaif. Hasil penelitian ini berupa buku pedoman pelaksanaan model permainan rintangan. Adapun permainan ini terdiri dari 11 variasi permainan rintangan yang disusun berdasarkan prinsip tumbuh kembang anak, teori ber-main, dan teori latihan kebugaran jasmani. Model permainan rintangan ini terdiri dari: (a) berguling samping dilanjutkan dengan lari lurus sejauh 10 meter, (b) lari cepat berjarak 10 m melewati rintangan kardus yang disusun bervariasi, (c) merobohkan semua cone yang berada di dalam area, (d) berlari zig-zag melintasi rintangan cone, (e) berlari melintasi rintangan papan titian, (f) walking on the moon menggunakan papan titian, (g) berlari memindahkan bola dengan shuttle run membentuk angka delapan jarak $5 \mathrm{~m}$ melewati rintangan tiang pancang, (h) lompat satu kaki melewati lingkaran, (i) pole flying, (j) lari balok, dan $(\mathrm{k})$ mengumpulkan cone dengan warna yang sesuai dengan petunjuk yang diterima. Dari hasil penilaian para ahli materi dapat ditarik kesimpulan bahwa model permainan rintangan yang dikembangkan sangat baik untuk latihan kebugaran jasmani anak usia 10-12 tahun sehingga model permainan layak digunakan.
\end{abstract}

Kata Kunci: model permainan rintangan (handicap games), kebugaran jasmani usia 10-12 tahun.

\section{Abstract}

This research aims to produce a handicap games model for practicing the physical fitness of 10-12 years old children. This research is a research and development study using the adaptation of the procedure proposed by Borg and Gall (1983) in seven steps e.i (1) collecting field information, (2) analyzing information, (3) developing the first draft, (4) validating models from experts and revising, (5) examining the models in narrow scale and revising, (6) examining the models in wide scale and revising and (7) producing the last product. The narrow scale examination was implemented to 40 students 10-12 years old of SD $N 1$ Klaten. The wide scale examination was implemented to 120 students of 10-12 years old of SD N 2 Klaten and SD N 4 Klaten. The data collecting instruments used were: (1) interview guide, (2) scoring scale form, (3) games observation sheet, and (4) games effectiness observation sheet. The data analysis technique used in this research is qualitative and quantitative descriptive. The result of this research is in the form of a manual book for practicing handicap games model for 10-12 years old students. The games consist of 11 variations of handicap games which are arranged in such a way based on the children's growth and development, playing theory, and theory of physical fitness exercises. The eleven variations include: (a) sides rolling continued by straight sprint, (b) sprint and jumping over a stack, (c) pushing down all the cones in the area, (d) zig-zag running, (e) running passing through a stepping board, $(f)$ walking on the, $(g)$ running and moving balls by shuttle run, $(h)$ jumping on one foot passing a circle, (i) pole flying, (j) running on a square wooden board, $(k)$ collecting cones with proper colors as mentioned in the instruction. From the experts' material evaluation, it can be concluded that the handicap games model is very good to practice the physical fitness of 10-12 years old students. Therefore, the games model is proper to be used.

Keywords: handicap games model, physical fitness, 10-12 years old children. 


\section{Pendahuluan}

Anak merupakan aset berharga suatu bangsa, karena anak pada gilirannya akan menjadi generasi penerus yang menjaga keberlangsungan kehidupan berbangsa dan bernegara. Maju mundurnya suatu bangsa tergantung pada kualitas sumber daya manusia masyarakat. Salah satu masa usia emas (golden age) dalam pembinaan fisik maupun mental anak adalah usia 10 sampai dengan 12 tahun. Negara-negara maju seperti USA, Inggris, Jerman, Jepang, dan yang lainnya, telah lama memberikan perhatian terhadap pentingnya pembinaan karakter secara berkelanjutan. Melihat urgensi fungsi dan peran anak di kemudian hari, maka perlu dilakukan pembinaan yang bersifat sistematis dan terencana. Untuk itu anak perlu disiapkan dan dibina dengan baik dengan menggunakan metode-metode ilmiah (scientific methods). Berdasarkan Human Development index (HDI) tahun 2010 Indonesia berada di peringkat 108 dari 169 negara (http://data.menkokesra.go.id).

Manusia adalah makhluk yang unik dan kompleks yaitu diciptakan lengkap dengan potensi jasmani dan rohani. Pembinaan terhadap anak harus dilakukan secara menyeluruh (holistik) dan tidak terpisah-pisah, yaitu seimbang antara pembinaan jasmani dan rohani. Dalam penjelasan pasal 1 Undang-undang No. 20 tahun 2003 tentang Sistem Pendidikan Nasional dijelaskan bahwa pendidikan adalah usaha sadar dan terencana untuk mewujudkan suasana belajar dan proses pembelajaran agar peserta didik secara aktif mengembangkan potensi dirinya untuk memiliki kekuatan spiritual keagamaan, pengendalian diri kepribadian, kecerdasan, akhlak mulia, serta keterampilan yang diperlukan dirinya, masyarakat, bangsa, dan negara. Berdasarkan fungsi pendidikan nasional tersebut adalah diharapkan muncul dan berkembangnya generasi penerus bangsa yang sehat. Berbicara mengenai sehat maka sangat erat kaitannya dengan kebugaran jasmani.

Pola orientasi penyelenggaraan pendidikan yang tidak seimbang akan memberikan dampak yang tidak seimbang pula terhadap perkembangan kehidupan anak. Hal yang perlu menjadi evaluasi adalah mengenai karakter manusianya. Pembentukan karakter sangat erat kaitannya dengan perkembangan sosial anak. Laxmi (1998, p.48) mengungkapkan bahwa beberapa faktor yang turut mempengaruhi perkembangan sosial anak adalah: (1) status sosial ekonomi dari keluarga, (2) tipe hubungan antara orang tua dan anggota keluarga, (3) posisi anak dalam keluarga, (4) perlakuan yang diterima dari keluarga, (5) metode adaptasi dalam merawat anak, (6) latar belakang keluarga teman bermainnya, serta (7) disiplin yang diterapkan dalam keluarga. Pembentukan watak dan karakter anak harus dimulai dari tingkat paling dini yaitu dari keluarga sebagai landasan pembentukan kepribadian anak sampai dengan berbagai tingkat pendidikan formal. Pendidikan di tingkat dasar mengembangkan kemampuan peserta didik yang bersifat umum, termasuk salah satunya adalah pendidikan jasmani yang mengembangkan kemampuan multilateral, kemampuan lokomotor dan nonlokomotor.

Kualitas individu anak tidak saja didasarkan pada kemampuan kognitif saja, melainkan juga aspek kebugaran jasmani. Kebugaran jasmani mempunyai peran yang sangat besar terhadap aktivitas keseharian anak. Kebugaran jasmani berfungsi untuk meningkatkan kemampuan kerja dan dapat melaksanakan tugastugasnya secara optimal. Kebugaran jasmani yang rendah manjadi masalah di berbagai negara. Anak-anak dan remaja yang memiliki kebugaran jasmani yang rendah, salah satu penyebabnya adalah pola hidup yang pasif dan kurang aktivitas jasmani. Permasalahan tersebut juga terjadi pada siswa sekolah dasar di Kabupaten Klaten, khususnya yang letak geografisnya berada di perkotaan. Sekolah yang berada di perkotaan memiliki kecenderungan dekat lalu lintas yang ramai, sehingga membuat orang tua tidak tega untuk membiarkan anak berangkat sekolah sendiri. Kondisi demikian menuntut orang tua untuk antar-jemput anak dengan kendaraan, sehingga mengurangi gerak anak dibandingkan anak-anak yang berangkat ke sekolah dengan bersepeda atau berjalan kaki. Ditambah lagi keterbatasan ruang terbuka untuk bermain di sekolah maupun kondisi ruang terbuka yang tidak mendukung untuk anak melakukan aktivitas jasmani juga menjadi faktor penting yang mempengaruhi pola gerak anak. Untuk itu anak perlu dilatih guna memenuhi kebutuhan akan aktivitas fisik. Metode latihan yang digunakan untuk meningkatkan kebugaran jasmani harus sesuai dengan fase pertumbuhan dan perkembangan anak.

Dalam praktik latihan terdapat banyak metode latihan yang dapat meningkatkan kebugaran jasmani, di antara: interval training, circuit training, jogging, fartlek, jogging dan aerobic. Namun demikian tidak semua jenis tersebut sesuai jika diberikan kepada anak-anak. 
Sering kali yang terjadi apabila metode yang diberikan tidak tepat maka yang terjadi adalah anak kehilangan motivasi dalam latihan, ogahogahan, dan tidak serius dalam melaksanakan latihan. Untuk itu perlu didesain jenis latihan yang dapat mengakomodasi kepentingan anak dari berbagai sudut pandang, baik secara fisik, psikis, dan fisiologis.

Anak usia 7 tahun pada umumnya usia anak memasuki sekolah dasar. Hal ini dengan pertimbangan bahwa pada usia tersebut anakanak sudah betul-betul siap untuk menerima beban pelajaran yang sesuai dengan fase pertumbuhan dan perkembangannya. Pada masa kanak-kanak ini sangat erat hubungannya dengan permainan dan bermain. Pada usia ini bermain hampir setiap saat dilakukan oleh anakanak. Hal ini dapat dimaklumi karena dunia anak adalah dunia bermain. Pada saat melakukan kegiatan bermain anak selalu melakukannya dengan gembira dan tanpa paksaan. Bermain merupakan segala kegiatan yang menimbulkan kesenangan bagi anak, dilakukan dengan suka rela tanpa paksaan, dan aturan dibuat sendiri oleh pelaku. Aktivitas bermain memiliki ciri-ciri sebagai berikut: dilakukan dengan suka rela, dilakukan secara spontan, berorientasi kepada proses bukan hasil, dan menghasilkan kepuasan.

Aktivitas jasmani yang didesain dengan model permainan akan menjadi sarana yang tepat untuk memenuhi kebutuhan anak terhadap gerak. Dari perspektif psikologi manusia bahwa dalam hal melakukan atau tidak melakukan sesuatu perlu adanya suatu minat atau dorongan yang disebut dengan motif. Minat dan motifasi menjadi peran sentral dalam menentukan keberhasilan suatu latihan. Dalam hal ini ada hubungan yang positif antara minat dan keberhasilan. Hal ini sesuai yang diungkapkan oleh Zuliyanti (2011, p.3) yang menyatakan bahwa semakin tinggi minat belajar maka semakin tinggi pula prestasi belajar yang dicapai. Hal senada juga diungkapkan oleh Andarmoyo (2011, p.13) yang menyatakan bahwa ada hubungan yang signifikan antara minat belajar dengan prestasi yang dicapai. Dua pendapat tersebut memberikan landasan akademis bahwa minat menentukan pencapaian tujuan yang direncanakan. Dalam konteks pendidikan jasmani, olahraga dan kesehatan tidak terlepas dari peran minat untuk mencapai suatu tujuan pembelajaran. Untuk menarik minat para siswa, harus ditempuh dengan berbagai cara. Salah satu cara tersebut adalah penggunaan metode bermain.
Bermain merupakan sarana penting dalam mengembangkan kemampuan jasmani anak, selain juga terdapat banyak nilai-nilai yang lain. Bermain juga merupakan hal penting dalam mengembangkan kemampuan jasmani. Model bermain merupakan upaya untuk memberikan variasi permainan yang dapat menarik minat anak untuk melakukan permainan, sebagai bentuk pemberian aktivitas jasmani secara menyeluruh. Pemberian aktivitas jasmani secara menyeluruh dapat dilakukan melalui berbagai aktivitas olahraga, mengisi waktu luang, atau dengan pembiasaan dalam kehidupan seharihari. Hal ini sesuai dengan yang diungkapkan oleh Branca dan Valuena (2001, p.121) bahwa "a good level of physical activity should be promoted in children of all ages through organised sport, leisure, and everyday habbits.

Dengan kondisi yang demikian, maka perlu pengembangan desain permainan yang sesuai dengan kebutuhan, tahap pertumbuhan dan perkembangan anak usia 10-12 tahun. Dalam penelitian ini, peneliti melakukan penelitian dan pengembangan berupa pengembangan model bermain menggunakan permainan rintangan (handicap games) untuk latihan kebugaran jasmani anak usia 10-12 tahun. Melalui berbagai permainan yang didesain menggunakan rintangan akan menimbulkan semangat yang lebih tinggi bagi anak untuk melakukan aktivitas bermain. Perkembangan psikologis anak pada usia 10-12 tahun salah satu cirinya adalah adalah selalu ingin beraktualisasi diri, mengeksplorasi lingkungan di sekitarnya, menyukai hal yang baru serta menantang. Desain permainan rintangan memberikan tantangan pada setiap bentuknya sehingga anak akan merasa harus melewati rintangan tersebut. Setiap kali anak melewati rintangan secara langsung namun secara tidak disadari akan memberikan dampak latihan fisik sehingga memberikan manfaat bagi tubuh.

Dari uraian tersebut, dapat diidentifikasi permasalahan sebagai berikut: (1) pola kehidupan sehari-hari yang sekarang ini dijalankan anak kurang merangsang perkembangan aspek jasmani secara optimal, (2) anak memiliki beban dan tuntutan yang besar dari orangtua sehingga membentuk paradigma berpikir yang parsial antara kebutuhan jasmani dan rohani, di mana pemenuhan kebutuhan rohani khususnya kognitif lebih diprioritaskan, (3) konsep dasar pendidikan di sekolah belum menekankan pada aspek fisik secara proporsional, (4) aktivitas bermain anak terkendala pada fasilitas dan mi- 
nimnya lokasi bermain yang memadai, (5) setiap sekolah belum menyediakan area bermain bagi anak, (6) kurangnya inovasi model permainan yang disesuaikan dengan kondisi sekolah yang memiliki keterbatasan tempat bermain. (7) aktivitas jasmani anak sering kali kurang terarah dalam memberikan dampak terhadap kebugaran jasmani, (8) metode yang digunakan dalam pengembangan kebugaran jasmani seringkali memberikan beban yang besar dan terasa membosankan, (9) model kegiatan yang berorientasi pada pengembangan kebugaran jasmani anak masih relatif kurang. (10) model kegiatan latihan kebugaran jasmani kurang variatif sehingga memberikan efek membosankan bagi anak. Dari berbagai permasalahan yang muncul dalam penelitian ini, peneliti hanya membatasi permasalahan pada model permainan rintangan untuk latihan kebugaran jasmani anak usia 10-12 tahun. Adapun rumusan masalah pada penelitian ini adalah bagaimana model permainan yang dapat digunakan untuk latihan kebugaran jasmani anak usia 10-12 tahun?

Penelitian ini bertujuan untuk mengembangkan model permainan yang sesuai dengan tahap perkembangan anak usia 10-12 tahun. Melalui penelitian diharapkan dihasilkan suatu bentuk model permainan rintangan untuk latihan kebugaran jasmani anak usia 10-12 tahun yang dikemas dalam sebuah buku pedoman pelaksanaan. Model yang disusun didasarkan pada karakteristik anak usia 10-12 tahun dan tingkat pertumbuhan serta perkembangannya.

Model permainan rintangan (handicap games) untuk latihan kebugaran jasmani anak usia 10-12 tahun yang dikemas dalam bentuk buku pedoman pelaksanaan ini digunakan untuk memudahkan guru penjasorkes maupun berbagai pihak yang relevan untuk melatih kebugaran jasmani anak didiknya. Keterbatasan dalam penelitian ini adalah bahwa keberadaan alat-alat yang dibutuhkan dalam permainan ini mutlak harus ada, apabila tidak terpenuhi akan mengurangi motivasi anak dalam melakukan permainan ini. Manfaat dari penelitian ini dapat dibedakan menjadi 2, yaitu: (1) tercipta model latihan yang sesuai dengan tahap perkembangan anak usia 10-12 tahun. (2) tercipta model latihan yang menyenangkan untuk mengembangkan kebugaran jasmani anak usia 10-12 tahun. (3) memperkaya khasanah pustaka kaitannya dengan pengembangan kebugaran jasmani siswa sekolah dasar. (4) memberikan pemahaman kepada orang tua akan kebutuhan gerak anak.

\section{Metode}

Penelitian ini merupakan penelitian dan pengembangan. Penelitian pengembangan (Research and development/R\&D) adalah metode penelitian yang digunakan untuk menghasilkan produk tertentu. Untuk dapat menghasilkan produk tertentu digunakan penelitian yang bersifat analisis kebutuhan dan untuk menguji keefektifan produk tersebut supaya dapat berfungsi di masyarakat luas, maka diperlukan penelitian untuk menguji produk tersebut. Penelitian pengembangan ini dilakukan untuk menghasilkan sebuah model permainan rintangan (handiap games) untuk latihan kebugaran jasmani anak usia 10-12 tahun.

\section{Prosedur Pengembangan}

Prosedur pengembangan merupakan langkah-langkah yang harus diikuti sebelum menghasilkan sebuah produk. Borg dan Gall (1983, p.75) menyatakan pada dasarnya prosedur penelitian dan pengembangan terdiri dari dua tujuan utama, yaitu mengembangkan produk (sebagai fungsi pengembangan) dan menguji keefektifan produk dalam mencapai tujuan (fungsi validasi). Prosedur atau langkah-langkah penelitian dan pengembangan tidak harus menggunakan langkah-langkah baku yang harus diikuti, tetapi setiap pengembang dapat memilih dan menentukan langkah yang paling tepat bagi penelitiannya berdasarkan kondisi dan kendala yang dihadapinya. Langkah-langkah penelitian dan pengembangan yang dimaksud adalah: (1) pengumpulan hasil riset dan informasi, (2) Perencanaan, (3) mengembangkan produk awal, (4) uji coba awal, (5) revisi penyusunan produk awal, (6) uji coba lapangan utama, (7) revisi penyusunan produk operasional, (8) uji coba produk operasional, (9) revisi produk akhir, dan (10) desiminasi dan implementasi produk hasil pengembangan.

Dari berbagai langkah yang dikemukakan tersebut, kemudian disesuaikan dengan kebutuhan dan keadaan yang sesungguhnya menjadi 7 langkah rancangan prosedur penelitian dan pengembangan. Prosedur penelitian dan pengembangan berdasarkan 7 langkah tersebut dapat dilihat dalam bagan prosedur penelitian dan pengembangan berikut ini:

\section{Pengumpulan Informasi}

Proses pengumpulan informasi diawali dengan peneliti melakukan observasi yang panjang terhadap proses keseharian pelaksanaan 
pembelajaran penjasorkes di beberapa sekolah dasar di perkotaan Kabupaten Klaten. Selain itu, peneliti juga melakukan interview (wawancara) menggunakan angket sederhana dengan guru penjasorkes yang menangani siswa secara langsung. Angket tersebut disusun khusus untuk menggali informasi terkait dengan permasalahan yang diangkat oleh peneliti. Proses berikutnya adalah dengan melakukan pengumpulan informasi lebih lanjut melalui studi pustaka untuk memberikan informasi penting dari sisi teori mengenai variabel dalam penelitian ini.

\section{Analisis Informasi}

Analisis dilakukan terhadap berbagai informasi yang berhasil dikumpulkan melalui proses observasi, wawancara (interview), maupun studi pustaka yang telah dilakukan. Observasi dilakukan untuk membangun pola berpikir peneliti dan membangun asumsi awal peneliti. Wawancara dilakukan untuk mengetahui kebenaran terhadap asumsi awal peneliti terhadap kondisi sebenarnya di lapangan. Sementara itu, untuk analisis melalui studi pustaka dimaksudkan untuk memfokuskan permasalahan atau variabel yang dikaji dalam penelitian ini. Kemudian disimpulkan mengenai permasalahan yang ada dalam pembelajaran penjasorkes khususnya latihan kebugaran jasmani menjadi kajian pokok dalam penelitian ini.

\section{Pengembangan Produk Awal}

Peneliti menyusun beberapa konsep suatu produk yang mengacu pada beberapa teori yang mendukung terhadap permainan dan kebugaran jasmani. Produk yang dikembangkan ini masih merupakan produk awal dan dalam pengembangannya dilakukan hal-hal sebagai berikut: (a) mengalisis jenis dan bentuk permainan yang sesuai dengan tahap perkembangan anak usia 10-12 tahun serta mengandung unsur pengembangan komponen kebugaran jasmani, (b) menganalisis muatan kognitif, afektif, psikomotor yang disesuaikan dengan teori perkembangan anak usia 10-12 tahun, serta disesuaikan dengan kebutuhan yang diperlukan, tujuannya agar produk sesuai dengan teori yang mendasarinya, (c) menganalisis dan menentukan format permainan yang mampu memberikan dampak besar terhadap fisik yaitu mengandung unsur latihan, dan unsur psikologis yaitu menimbulkan rasa tertarik dan senang untuk melaksanakan permainan ini. Dalam hal ini peneliti melakukan pengembangan format produk awal berupa model permainan rintangan (handicap games) yang terdiri dari 11 variasi latihan model permainan rintangan, dimana setiap variasi latihan permainan mengandung unsur rintangan yang penuh dengan tantangan. Model permainan rintangan (handicap games) tersebut dikemas dalam bentuk buku pedoman pelaksanaan permainan

\section{Validasi Ahli dan Revisi}

Validasi dilakukan dengan responden para ahli ntuk mendapatkan masukan maupun pengesahan yang sesuai dengan konsep latihan kebugaran jasmani, perkembangan anak usia 10-12 tahun, kebutuhan dalam pelaksanaan pembelajaran pendidikan jasmani, serta produk yang ingin dikembangkan. Kegiatan ini dilakukan untuk review produk awal, memberikan masukan untuk perbaikan. Proses validasi ini disebut dengan expert judgement. Penelitian ini menggunakan 3 pakar yang sesuai dengan bidangnya masing-masing ditambah dengan 1 orang ahli pakar lapangan yaitu guru Penjasorkes sekolah dasar. Ketiga pakar tersebut adalah Prof. Dr. Sukadiyanto, M.Pd sebagai pakar pendidikan usia dini, Prof. Dr. Suharjana, M.Kes sebagai pakar kebugaran jasmani, dan Heri Purwanto, S.Pd. sebagai pakar media. Selain ketiga pakar tersebut juga ditambah dengan satu orang pakar lapangan yaitu, Suharjo, S.Pd selaku guru penjasorkes di SD Negeri 1 Klaten. Setiap pakar diminta untuk menilai desain tersebut sehingga selanjutnya dapat diketahui kelemahan dan kelebihannya. Proses validasi ahli menilai materi dan memberikan masukan terhadap produk awal yang disusun. Berdasarkan hal tersebut, dilakukan revisi produk awal kemudian dilanjutkan dengan uji coba.

\section{Uji Coba Skala Kecil dan Revisi}

Uji coba skala kecil dilakukan terhadap 30-40 siswa dari SD Negeri 1 Klaten. Pelaksanaan uji coba ini, guru penjasorkes melakukan pembelajaran sesuai dengan desain permainan yang telah disusun peneliti, sementara itu peneliti melakukan pengamatan dan mencatat hal penting selama proses berlangsung, baik aktivitas anak maupun guru. Proses selanjutnya peneliti melakukan diskusi dengan guru yang bersangkutan terkait dengan proses yang telah dilaksanakan, guru dapat memberikan masukan dan saran untuk perbaikan dan penyempurnaan model permainan yang dibuat. Pada saat dan setelah uji coba ini dilakukan pengamatan, diskusi dan wawancara kemudian melakukan analisis terhadap hasil yang dijadikan sebagai ba- 
han pertimbangan untuk revisi produk. Untuk mempertahankan objektifitas dan mengetahui proses yang dilakukan, peneliti melakukan pendokumentasian dengan alat elektronik yaitu handycam dan camera.

\section{Uji Coba Skala Besar dan Revisi}

Uji coba skala besar dilaksanakan pada 2 sekolah yaitu di SD Negeri 2 Klaten dan SD Negeri 4 Klaten. Proses revisi dilakukan setelah mendapat masukan dari para ahli materi untuk menghasilkan produk akhir. Proses revisi ini dilakukan apabila dalam uji coba skala besar terdapat kelemahan dan kekurangan.

\section{Produk Akhir}

Apabila model permainan rintangan (handicap games) tersebut telah dinyatakan baik, maka model tersebut dapat diterapkan dalam proses pembelajaran untuk latihan kebugaran jasmani anak usia 10-12 tahun.

\section{Uji Coba Produk}

\section{Desain Uji Coba}

Desain uji coba dalam penelitian ini menggunakan desain eksperimental. Untuk uji coba produk dalam penelitian ini menggunakan dua (2) tahap yang dilalui, yaitu uji skala kecil dan uji skala besar.

\section{Subjek Uji Coba}

Subjek uji coba dalam penelitian ini adalah anak usia 10-12 tahun. Uji coba skala kecil dilaksanakan di SD Negeri 1 Klaten, dan untuk uji coba skala besar dilaksanakan di SD Negeri 2 Klaten dan SD Negeri 4 Klaten.

\section{Jenis Data}

Data yang diperoleh dari proses penelitian ini adalah data kualitatif dan kuantitatif. Data kualitatif diperoleh dari hasil observasi pembelajaran dan kuesioner yang berupa masukan dan saran dari para ahli dan guru penjasorkes sekolah dasar untuk pembenahan atau revisi produk, serta lembar pengamatan dari para ahli. Selanjutnya data kuantitatif diperoleh dari hasil penilaian lembar pengamatan dari para ahli. Data-data yang diperoleh tersebut digunakan untuk evaluasi model permainan rintangan (handicap games) untuk latihan kebugaran jasmani anak usia 10-12 tahun.

\section{Instrumen Pengumpulan Data}

Instrumen pengumpulan data dalam penelitian ini menggunakan pedoman observasi dan wawancara menggunakan kuesioner. Teknik pengumpulan data yang pertama digunakan adalah melalui interview atau wawancara langsung dengan narasumber yang bersangkutan. Definisi dari teknik komunikasi langsung adalah pengumpulan data yang dilakukan melalui hubungan komunikasi secara langsung yang disampaikan dengan lisan (Nawawi \& Martini, 2006, p.98). Pedoman wawancara berbentuk butir-butir pertanyaan yang perlu disampaikan yang disusun berdasarkan permasalahan mengenai variabel dari penelitian ini. Bentuk wawancara yang dilakukan yaitu dengan menggunakan wawancara bebas dan terpimpin. Pedoman wawancara tidak berbentuk seperangkat pertanyaan, hanya berbentuk butir pertanyaan yang perlu disampaikan berkaitan dengan variabel penelitian. Peneliti menyusun pertanyaan tentang butir-butir yang akan diberikan kepada responden dengan isi yang sama terhadap setiap responden.

Pertanyaan yang disusun berdasarkan tujuan pelaksanaan wawancara, yaitu untuk menggali proses latihan kebugaran jasmani dan kondisi status kebugaran jasmani anak usia 1012 tahun di setiap sekolah, serta masalah dalam melakukan latihan kebugaran jasmani anak. Butir pertanyaan meliputi (1) proses pembelajaran yang berkaitan dengan latihan kebugaran jasmani sesuai dengan karakteristik anak usia 10-12 tahun apa tidak, (2) permainan-permainan yang sering digunakan untuk latihan kebugaran jasmani anak, (3) pemahaman guru terhadap hakikat kebugaran jasmani dan cara melatihnya, (4) status kebugaran jasmani anak, (5) kesulitan yang dialami guru dalam latihan kebugaran jasmani anak.

\section{Skala Nilai}

Skala ini digunakan untuk menilai model permainan yang dikembangkan sebelum pelaksanaan uji coba skala kecil. Setiap ahli memberikan persetujuan sekaligus menilai tentang model permainan rintangan (handicap games) sudah mengacu pada skala nilai, baru model permainan rintangan (handicap games) dapat diujicobakan skala kecil. Kategori yang dimaksud dalam skala ini adalah kategori berskala dua yang terdiri dari jawaban ya dan tidak. Apabila unsur seperti yang terdapat dalam klasifikasi data dinyatakan "Ya" maka nilainya satu (1), dan apabila dinyatakan "tidak" maka nilainya nol (0).

Sesuai penelitian ini yaitu membuat model permainan rintangan untuk latihan 
kebugaran jasmani anak usia 10-12 tahun dapat diuraikan klasifikasi unsur yang ada di dalamnya. Sasaran model permainan rintangan untuk latihan kebugaran jasmani anak usia 10-12 tahun disesuaikan dengan karakteristiknya, yaitu: (1) model permainan rintangan menyenangkan sehingga anak dapat melakukan aktivitas bermain sesuai dengan asas bermain yaitu senang, tanpa paksaan, dan memperoleh kepuasan, (2) permainan rintangan mampu mendorong anak aktif bergerak. (3) model permainan rintangan dapat dilaksanakan dalam suasana yang tidak terlalu sulit sehingga mudah bagi guru untuk menyampaikannya. (4) alat mudah diperoleh dan tidak membahayakan bagi anak.

Unsur-unsur tersebut dijabarkan dan disusun secara teratur menjadi daftar klasifikasi yang digunakan untuk menilai sesuai atau tidaknya model permainan yang dikembangkan dengan unsur-unsur klasifikasi skala nilai.

\section{Observasi}

Teknik pengumpulan data dengan menggunakan observasi tidak langsung. Teknik observasi tidak langsung merupakan cara mengumpulkan data yang dilakukan melalui pengamatan dan pencatatan dari gejala-gejala yang tampak pada objek penelitian yang dilakukan setelah peristiwa dan keadaan terjadi (Nawawi \& Martini, 2006, pp.67-68). Pengamatan dan pencatatan dilakukan menggunakan daftar cek dan peralatan elektronik berupa handycam dan camera digital, hal ini bertujuan agar pengamatan terdokumentasikan dan untuk mejaga objektifitas dalam penelitian ini. Untuk menggunakan daftar cek, harus terlebih dahulu menjabarkan variabel penelitian secara lengkap yang di dalamnya terdapat unsur di dalam setiap gejala. Rincian gejala dan unsur-unsur disusun secara teratur menjadi suatu daftar sebagai urutan klasifikasi data yang akan diamati muncul atau tidaknya di dalam suatu peristiwa yang berkenan dengan masalah penelitian (Nawawi \& Martini, 2006, pp.76-77).

Untuk alat bantu elektronik berupa handycam dan camera digital digunakan untuk mengetahui hal-hal yang terjadi selama proses berlangsung, sehingga pengamatan dan analisis dapat dilakukan setelah peristiwa itu terjadi. Di sisi lain, penggunaan alat juga sangat mempengaruhi hasil kegiatan sehingga peneliti bekerjasama dengan orang yang kompeten untuk mengoperasionalkan peralatan tersebut. Sudut pandang pengambilan ditentukan oleh peneliti agar unsur yang diperlukan terhadap tujuan penelitian dapat dicapai.

\section{Teknik Analisis Data}

Teknik analisis data yang digunakan adalah analisis deskriptif kuantitatif dan kualitatif. Analisis data kuantitatif digunakan untuk menganalisis data-data yaitu: (a) data skala nilai berupa hasil penilaian para ahli terhadap model permainan yang dikembangkan, (b) data hasil observasi para ahli terhadap model permainan yang dikembangkan. Sedangkan analisis deskriptif kualitatif digunakan dalam melakukan analisis terhadap data masukan dan kekurangan model permainan yang dikembangkan baik sebelum maupun sesudah uji coba.

Draf model dinyatakan layak untuk dilakukan uji coba pada skala kecil apabila para ahli telah memberikan validasi dan menyatakan semua item dianggap sesuai dengan memberikan tanda cek $(\sqrt{ })$ pada kolom "Ya" yang bernilai satu (1) atau pada kolom "Tidak" yang bernilai nol (0). Hasil penilaian terhadap setiap item observasi dijumlahkan, kemudian nilai yang didapat dikonversikan sesuai tabel kategori (tabel). Konversi yang dilakukan dengan mengikuti standar Penilaian Acuan Patokan (PAP). Rentang nilai yang digunakan adalah sebagai berikut:

Tabel 1. Penilaian Acuan Patokan Sebagai Patokan Konversi Hasil Observasi

\begin{tabular}{ccc}
\hline $\begin{array}{c}\text { Rentang Skor } \\
\text { Nilai }\end{array}$ & Kategori & Keterangan \\
\hline $80 \%-100 \%$ & A & Sangat Baik \\
$70 \%-79 \%$ & B & Baik \\
$60 \%-69 \%$ & C & Cukup Baik \\
$45 \%-59 \%$ & D & Kurang Baik \\
$<45 \%$ & E & Sangat Kurang Baik \\
\hline
\end{tabular}

\section{Hasil Penelitian dan Pengembangan}

Data Uji Coba

Draf awal model permainan rintangan ini, terdiri dari satu paket permainan yang berisi 11 variasi permainan. Secara lengkap permainan rintangan ini adalah sebagai berikut: (a) berguling samping dilanjutkan dengan lari lurus sejauh 10 meter, (b) lari rintangan kardus, (c) merobohkan semua cone yang berada di dalam area, (d) berlari zig-zag melintasi rintangan cone, (e) berlari rintangan papan titian, (f) walking on the moon, $(\mathrm{g})$ berlari memindahkan bola dengan shuttle run, (h) lompat satu kaki (engklek) melewati lingkaran, (i) pole flying, (j) lari balok, dan (k) mengumpulkan cone dengan 
warna yang sesuai dengan petunjuk yang diterima.

\section{Data Masukan Ahli Materi}

Pengajuan draf awal model permainan rintangan terhadap ahli materi mendapatkan masukan mengenai isi materi, (a) menganalisis muatan kognitif, afektif, psikomotor yang disesuaikan dengan kajian teori perkembangan anak usia 10-12 tahun, serta disesuaikan dengan kebutuhan, tujuannya agar produk relevan dengan teori dan tujuan pengembangan, (b) Menganalisis kebutuhan gerak yang sesuai dengan karakteristik anak usia 10-12 tahun, (c) menganalisis model terhadap kebutuhan guru pendidikan jasmani dalam proses pembelajaran kebugaran jasmani di sekolah. Berikut ini adalah rincian beberapa masukan ahli terhadap draf awal yang telah diajukan kepada para ahli materi.

Tabel 2. Masukan Terhadap Permainan Guling Samping Dilanjutkan Lari Lurus 10 Meter

\begin{tabular}{|c|c|}
\hline Ahli materi & Masukan \\
\hline $\begin{array}{l}\text { Kebugaran } \\
\text { jasmani }\end{array}$ & $\begin{array}{l}\text { - Model harus merangsang anak } \\
\text { untuk bergerak } \\
\text { - Model latihan harus mengandung } \\
\text { komponen kebugaran jasmani }\end{array}$ \\
\hline Anak usia dini & $\begin{array}{l}\text { - Model harus dilakukan dalam } \\
\text { bentuk bermain } \\
\text { - Model disesuaikan dengan karak- } \\
\text { teristik anak usia } 10-12 \text { tahun } \\
\text { - Model mampu membuat anak } \\
\text { ber-gerak dengan senang }\end{array}$ \\
\hline Media & $\begin{array}{l}\text { - Petunjuk pelaksanaan diperjelas } \\
\text { - Gambar membantu memudahkan } \\
\text { memahami teknis pelaksanaan }\end{array}$ \\
\hline $\begin{array}{l}\text { Guru } \\
\text { pendidikan } \\
\text { jasmani/pakar } \\
\text { lapangan }\end{array}$ & $\begin{array}{l}\text { - Model latihan membuat anak } \\
\text { tertarik untuk melaksanakannya. } \\
\text { - Model latihan harus mengandung } \\
\text { unsur keselamatan yang tinggi } \\
\text { - Model latihan harus memberikan } \\
\text { variasi latihan yang tidak } \\
\text { membosankan } \\
\text { - Model latihan harus mudah } \\
\text { dilaksanakan }\end{array}$ \\
\hline
\end{tabular}

Tabel 3. Masukan Terhadap Permainan Lari ZigZag Melewati Rintangan Cone

\begin{tabular}{ll}
\hline \multicolumn{1}{c}{ Ahli materi } & \multicolumn{1}{c}{ Masukan } \\
\hline Kebugaran & - Model latihan harus mengandung \\
jasmani & komponen kebugaran jasmani \\
& - Urutan variasi perlu disesuaikan \\
Anak usia & - Model harus dilakukan dalam \\
dini & bentuk bermain \\
& - Model disesuaikan dengan karak- \\
& teristik anak usia 10-12 tahun \\
& - Model mampu memberikan \\
& dampak positif terhadap anak \\
& yaitu muncul-nya rasa senang dan \\
& gembira pada saat melaksanakan \\
& permainan \\
- Isi dipersingkat dan jelas & Model latihan membuat anak \\
Guru & tertarik untuk melaksanakannya. \\
pendidikan & Model latihan harus mengandung \\
jasmani/pakar & unsur keselamatan yang tinggi \\
lapangan & Model latihan harus memberikan \\
& va-riasi latihan yang tidak \\
& membosankan
\end{tabular}

Tabel 4. Masukan Terhadap Permainan Merobohkan Semua Cone yang Ada di Dalam Area

\begin{tabular}{|c|c|}
\hline Ahli materi & Masukan \\
\hline $\begin{array}{l}\text { Kebugaran } \\
\text { jasmani }\end{array}$ & $\begin{array}{l}\text { - Model latihan mendorong anak } \\
\text { untuk aktif bergerak } \\
\text { - Model latihan harus mengandung } \\
\text { komponen kebugaran jasmani }\end{array}$ \\
\hline $\begin{array}{l}\text { Anak } \\
\text { dini }\end{array}$ & $\begin{array}{l}\text { - Model harus dilakukan dalam } \\
\text { bentuk bermain } \\
\text { - Model disesuaikan dengan karak- } \\
\text { teristik anak usia 10-12 tahun } \\
\text { - Model mampu memberikan dam- } \\
\text { pak positif terhadap anak yaitu } \\
\text { munculnya rasa senang dan } \\
\text { gembira }\end{array}$ \\
\hline Media & $\begin{array}{l}\text { - Gambar memperjelas teknis pelak- } \\
\text { sanaan }\end{array}$ \\
\hline $\begin{array}{l}\text { Guru } \\
\text { pendidikan } \\
\text { jasmani/pakar } \\
\text { lapangan }\end{array}$ & $\begin{array}{l}\text { - Model latihan membuat anak } \\
\text { tertarik untuk melaksanakannya. } \\
\text { - Model latihan harus mengandung } \\
\text { unsur keselamatan yang tinggi } \\
\text { - Model latihan harus memberikan } \\
\text { variasi latihan yang tidak mem- } \\
\text { bosankan } \\
\text { - Model latihan harus mudah dilak- } \\
\text { sanakan } \\
\text { - Penataan warna cone secara acak }\end{array}$ \\
\hline
\end{tabular}


Tabel 5. Masukan Terhadap Permainan Lari Cepat Berjarak 10 m Melewati Rintangan Kardus yang Disusun Bervariasi

\begin{tabular}{ll}
\hline \multicolumn{1}{c}{ Ahli materi } & \multicolumn{1}{c}{ Masukan } \\
\hline Kebugaran & - Cara melompat kardus disesuaikan \\
jasmani & dengan kapasitas anak \\
& - Model latihan harus mengandung \\
& komponen kebugaran jasmani \\
Anak usia & - Model harus dilakukan dalam \\
dini & bentuk bermain \\
& - Model disesuaikan dengan karak- \\
& teristik anak usia 10-12 tahun \\
& - Model mampu mendorong untuk \\
& ber-geak dengan senang \\
- & Istilah tujuan permainan disesuai- \\
Media & kan \\
- & Model latihan membuat anak \\
Guru & tertarik untuk melaksanakannya. \\
pendidikan & Model latihan harus mengandung \\
jasmani/pakar & unsur keselamatan yang tinggi \\
lapangan & Model latihan harus memberikan \\
& variasi latihan yang tidak mem- \\
& bosankan
\end{tabular}

Tabel 6. Masukan Terhadap Permainan Lari Melewati Rintangan Papan Titian

\begin{tabular}{ll}
\hline Ahli materi & \multicolumn{1}{c}{ Masukan } \\
\hline Kebugaran & - Model latihan harus mengandung \\
jasmani & komponen kebugaran jasmani \\
& - Aspek keselamatan perlu diperhati- \\
& kan \\
Anak usia & - Model harus dilakukan dalam ben- \\
dini & tuk bermain \\
& - Model disesuaikan dengan karak- \\
& teristik anak usia 10-12 tahun \\
& - Model mampu mendorong bergerak \\
& - Model latihan mengakomodasi ke- \\
& butuhan pertumbuhan dan perkem- \\
& bangan anak \\
& - Petunjuk pelaksanaan diperjelas \\
- & Gambar membantu memudahkan \\
& memahami teknis pelaksanaan \\
Media & Model latihan membuat anak ter- \\
& tarik untuk melaksanakannya. \\
Guru & Model latihan harus mengandung \\
pendidikan & unsur keselamatan yang tinggi \\
jasmani/ & Model latihan harus memberikan \\
pakar & variasi latihan yang tidak mem- \\
lapangan & bosankan \\
& - Model latihan harus mudah dilaksa- \\
& nakan \\
&
\end{tabular}

Tabel 7. Masukan Terhadap Permainan Walking On The Moon Menggunakan Papan Titian

\begin{tabular}{|c|c|}
\hline Ahli I & Masukan \\
\hline $\begin{array}{l}\text { Kebugaran } \\
\text { jasmani }\end{array}$ & $\begin{array}{l}\text { - Model latihan harus mengandung } \\
\text { komponen kebugaran jasmani } \\
\text { - Jarak antarpapan perlu diatur untuk } \\
\text { memberikan dampak pembebanan }\end{array}$ \\
\hline $\begin{array}{l}\text { Anak } \\
\text { dini }\end{array}$ & $\begin{array}{l}\text { - Model harus dilakukan dalam } \\
\text { bentuk bermain } \\
\text { - Model disesuaikan dengan karak- } \\
\text { teristik anak usia 10-12 tahun } \\
\text { - Model mampu memberikan dam- } \\
\text { pak positif terhadap anak yaitu } \\
\text { munculnya rasa senang dan } \\
\text { gembira } \\
\text { - Model latihan mengakomodasi ke- } \\
\text { butuhan pertumbuhan dan perkem- } \\
\text { bangan anak }\end{array}$ \\
\hline Media & $\begin{array}{l}\text { - Petunjuk pelaksanaan diperjelas } \\
\text { - Gambar membantu memudahkan } \\
\text { memahami teknis pelaksanaan }\end{array}$ \\
\hline $\begin{array}{l}\text { Guru } \\
\text { pendidikan } \\
\text { jasmani/pakar } \\
\text { lapangan }\end{array}$ & $\begin{array}{l}\text { - Model latihan membuat anak } \\
\text { tertarik untuk melaksanakannya. } \\
\text { - Model latihan harus mengandung } \\
\text { unsur keselamatan yang tinggi } \\
\text { - Model latihan harus memberikan } \\
\text { variasi latihan yang tidak mem- } \\
\text { bosankan } \\
\text { - Model latihan harus mudah dilak- } \\
\text { sanakan }\end{array}$ \\
\hline
\end{tabular}

Tabel 8. Masukan terhadap Permainan Berlari Memindahkan Bola dengan Shuttle Run Membentuk Angka Delapan Jarak 5 m Melewati Rintangan Tiang Pancang

\begin{tabular}{|c|c|}
\hline Ahli materi & Masukan \\
\hline $\begin{array}{l}\text { Kebugaran } \\
\text { jasmani }\end{array}$ & $\begin{array}{l}\text { - Model latihan harus mengandung } \\
\text { komponen kebugaran jasmani } \\
\text { - Aspek keselamatan perlu diperhati- } \\
\text { kan }\end{array}$ \\
\hline $\begin{array}{l}\text { Anak } \\
\text { dini }\end{array}$ & $\begin{array}{l}\text { - Model harus dilakukan dalam ben- } \\
\text { tuk bermain } \\
\text { - Model disesuaikan dengan karak- } \\
\text { teristik anak usia 10-12 tahun } \\
\text { - Model mampu memberikan dam- } \\
\text { pak positif terhadap anak yaitu } \\
\text { munculnya rasa senang dan } \\
\text { gembira }\end{array}$ \\
\hline Media & $\begin{array}{l}\text { - Petunjuk pelaksanaan diperjelas } \\
\text { - Gambar membantu memudahkan } \\
\text { memahami teknis pelaksanaan }\end{array}$ \\
\hline $\begin{array}{l}\text { Guru } \\
\text { pendidikan } \\
\text { jasmani/pak } \\
\text { ar lapangan }\end{array}$ & $\begin{array}{l}\text { - Model latihan membuat anak } \\
\text { tertarik untuk melaksanakannya. } \\
\text { - Model latihan harus mengandung } \\
\text { unsur keselamatan yang tinggi } \\
\text { - Model latihan harus memberikan } \\
\text { variasi latihan yang tidak } \\
\text { membosankan }\end{array}$ \\
\hline
\end{tabular}


Tabel 9. Masukan Terhadap Permainan Berlari Lompat Satu Kaki Melewati Lingkaran

\begin{tabular}{|c|c|}
\hline Ahli materi & Masukan \\
\hline $\begin{array}{l}\text { Kebugaran } \\
\text { jasmani }\end{array}$ & $\begin{array}{l}\text { - Model latihan harus mengandung } \\
\text { komponen kebugaran jasmani } \\
\text { - Jarak antar lingkaran disesuaikan }\end{array}$ \\
\hline $\begin{array}{l}\text { Anak } \\
\text { dini }\end{array}$ & $\begin{array}{l}\text { - Model harus dilakukan dalam } \\
\text { bentuk bermain } \\
\text { - Model disesuaikan dengan karak- } \\
\text { teristik anak usia 10-12 tahun } \\
\text { - Model mampu memberikan dampak } \\
\text { positif terhadap anak yaitu muncul- } \\
\text { nya rasa senang dan gembira } \\
\text { - Model latihan mengakomodasi ke- } \\
\text { butuhan pertumbuhan dan perkem- } \\
\text { bangan anak }\end{array}$ \\
\hline Media & $\begin{array}{l}\text { - Petunjuk pelaksanaan diperjelas } \\
\text { - Gambar membantu memudahkan } \\
\text { memahami teknis pelaksanaan }\end{array}$ \\
\hline $\begin{array}{l}\text { Guru } \\
\text { pendidikan } \\
\text { jasmani/ } \\
\text { pakar }\end{array}$ & $\begin{array}{l}\text { - Model latihan membuat anak } \\
\text { tertarik untuk melaksanakannya. } \\
\text { - Model latihan harus mengandung } \\
\text { unsur keselamatan yang tinggi }\end{array}$ \\
\hline lapangan & $\begin{array}{l}\text { - Model latihan harus memberikan } \\
\text { variasi latihan yang tidak mem- } \\
\text { bosankan } \\
\text { - Model latihan harus mudah dilak- } \\
\text { sanakan }\end{array}$ \\
\hline
\end{tabular}

Tabel 10. Masukan untuk Permainan Pole Flying

\begin{tabular}{|c|c|}
\hline Ahli materi & Masukan \\
\hline $\begin{array}{l}\text { Kebugaran } \\
\text { jasmani }\end{array}$ & $\begin{array}{l}\text { - Model latihan harus mengandung } \\
\text { komponen kebugaran jasmani } \\
\text { - Perhatikan aspek keselamatan }\end{array}$ \\
\hline $\begin{array}{l}\text { Anak } \\
\text { dini }\end{array}$ & $\begin{array}{l}\text { - Model harus dilakukan dalam } \\
\text { bentuk bermain } \\
\text { - Model disesuaikan dengan karak- } \\
\text { teristik anak usia 10-12 tahun } \\
\text { - Model mampu memberikan dam- } \\
\text { pak positif terhadap anak yaitu } \\
\text { munculnya rasa senang dan } \\
\text { gembira } \\
\text { - Model latihan mengakomodasi ke- } \\
\text { butuhan pertumbuhan dan per- } \\
\text { kembangan anak }\end{array}$ \\
\hline Media & $\begin{array}{l}\text { - Petunjuk pelaksanaan diperjelas } \\
\text { - Gambar membantu memudahkan } \\
\text { memahami teknis pelaksanaan }\end{array}$ \\
\hline \multirow[t]{2}{*}{$\begin{array}{l}\text { Guru } \\
\text { pendidikan } \\
\text { jasmani/pakar } \\
\text { lapangan }\end{array}$} & $\begin{array}{l}\text { - Model latihan membuat anak } \\
\text { tertarik untuk melaksanakannya. } \\
\text { - Model latihan harus mengandung } \\
\text { unsur keselamatan } \\
\text { - Model latihan harus memberikan } \\
\text { variasi latihan yang tidak mem- } \\
\text { bosankan }\end{array}$ \\
\hline & $\begin{array}{l}\text { - Model latihan harus mudah } \\
\text { dilaksanakan }\end{array}$ \\
\hline
\end{tabular}

Tabel 11. Masukan Terhadap Permainan Lari Balok

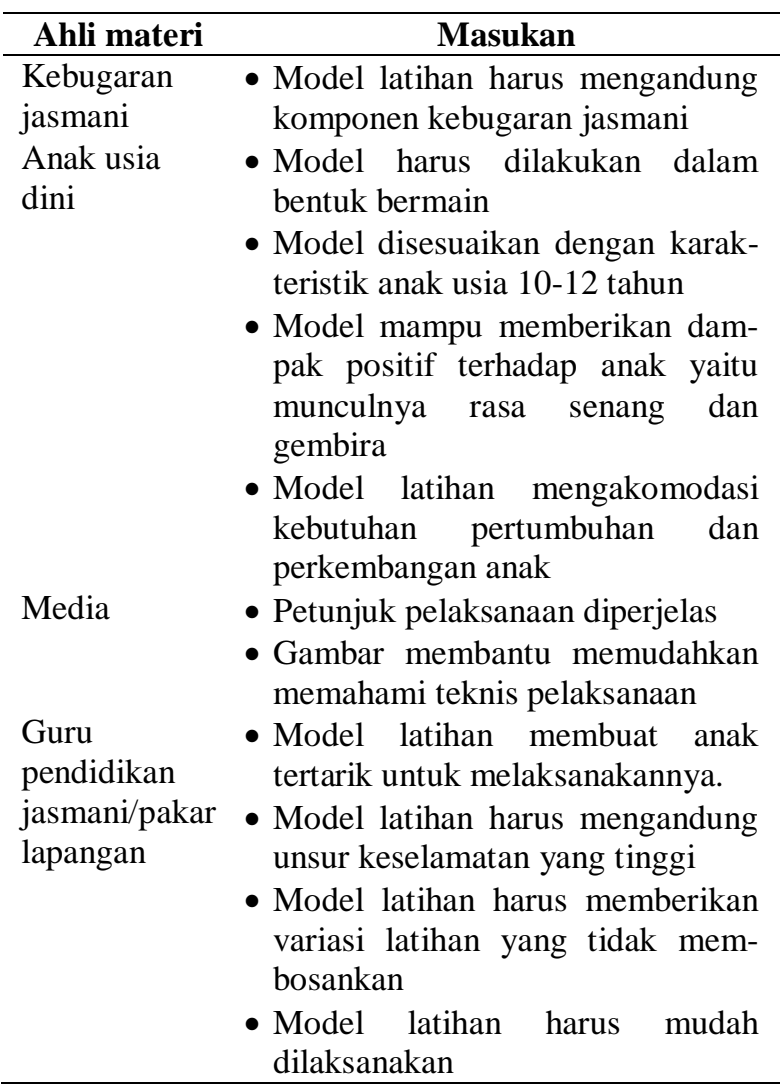

Tabel 12. Masukan Terhadap Permainan Lari Mengumpulkan Cone dengan Warna yang Sesuai dengan Petunjuk yang Diterima

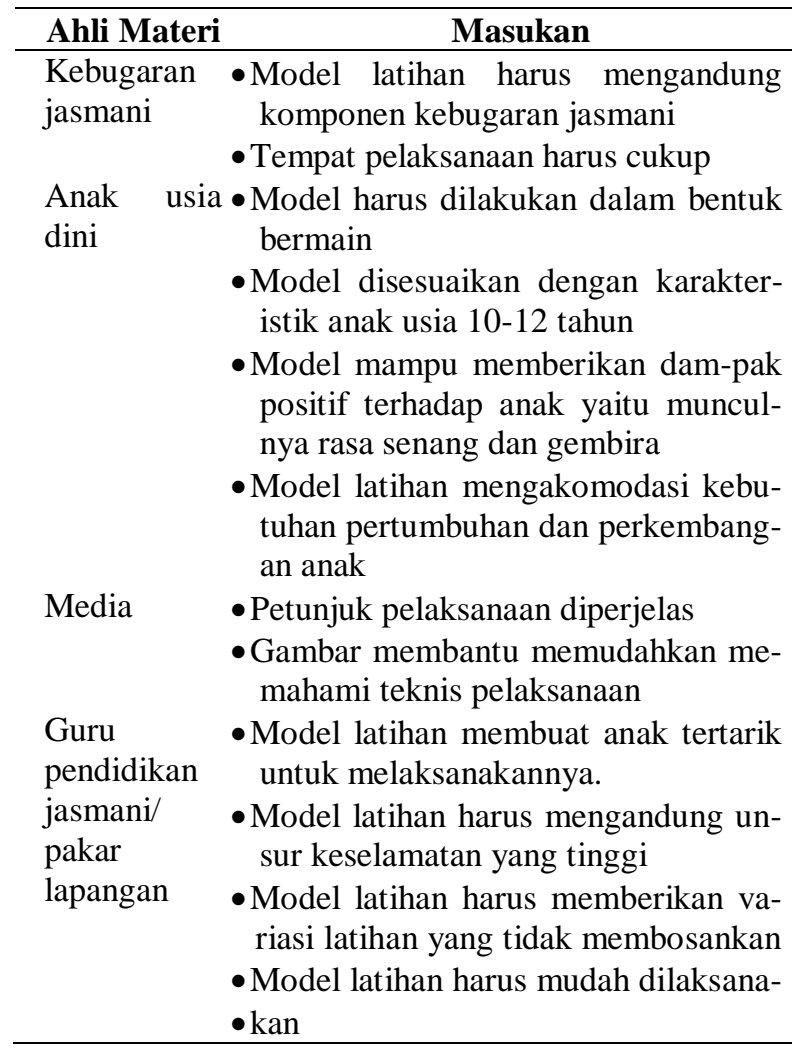


Analisis Data Permainan Guling Samping Dilanjutkan Lari Lurus 10 Meter.

Penilaian observasi ahli terhadap permainan ini menyatakan bahwa permainan ini masuk dalam kategori sangat baik. Sebagian besar ahli berpendapat latihan ini mampu memberikan dampak secara psikologis memberikan rasa gembira dan memnuhi aspek tantangan, serta melatihkan komponen kecepatan reaksi, serta melatih keberanian.

\section{Analisis Data Permainan Lari Melewati Rintangan Kardus}

Penilaian observasi ahli materi terhadap model permainan ini menyatakan bahwa model permainan ini masuk dalam kategori yang sangat baik. Beberapa ahli memiliki pendapat yang sama dan penilaian yang baik sehingga model ini sangat baik untuk latihan kebugaran jasmani. Adapun aspek psikomotorik yang dikembangkan melalui permainan ini adalah kecepatan, kelincahan, kekuatan, keseimbangan, dan ketepatan pada sasaran. Aspek kognitif yang dapat dilatihkan melalui permainan ini adalah siswa dapat berpikir dengan cepat dan memutuskan dengan tepat terkait cara melewati rintangan yang sedang dihadapi. Aspek afektif juga dapat dikembangkan melalui permainan ini, yaitu sikap dengan semangat yang tinggi anak dapat terangsang untuk melakukan permainan ini dengan gembira. Dalam permainan ini, ketika anak menghadapi rintangan, maka sikap anak adalah segera berpikir dengan cepat untuk melewati, bukan sebaliknya yaitu berhenti dan diam.

\section{Analisis Data Permainan Rintangan Meroboh- kan Semua Cone yang Berada di Dalam Area}

Penilaian observasi ahli materi terhadap permainan rintangan ini menyatakan bahwa model ini termauk kategori sangat baik digunakan untuk latihan kebugaran jasmani anak usia 10-12 tahun baik ranah kognitif, afektif, maupun psikomotrik. Pengembangan yang dilakukan melalui model permainan ini adalah kecepatan reaksi.

\section{Analisis Data Permainan Melewati Rintangan Cone Zig-Zag}

Penilaian observasi ahli materi terhadap model permainan melewati rintangan ini menyatakan bahwa model permainan ini termasuk dalam kategori yang sangat baik. Sebagian besar ahli berpendapat dan menilai bahwa permainan ini sangat baik digunakan untuk latihan kebugaran jasmani. Aspek psikomotorik yang dikembangkan melalui permainan ini adalah kelincahan, kecepatan, dan keseimbangan. Aspek afektif yang dapat dikembangkan melalui permainan ini adalah sikap untuk mengambil keputusan dengan cepat, keberanian, dan percaya diri.

\section{Analisis Data Permainan Berlari Melintasi Rintangan Papan Titian}

Penilaian observasi ahli materi terhadap permainan rintangan ini menyatakan bahwa model ini termasuk kategori sangat baik digunakan untuk latihan kebugaran jasmani anak usia 10-12 tahun baik ranah kognitif, afektif, maupun psikomotrik. Pengembangan yang dilakukan melalui model permainan ini adalah kecepatan reaksi.

\section{Analisis Data Permainan Walking On The Moon Menggunakan Papan Titian}

Penilaian observasi ahli materi terhadap permainan ini menyatakan bahwa model ini termasuk kategori sangat baik digunakan untuk latihan kebugaran jasmani anak usia 10-12 tahun baik ranah kognitif, afektif, maupun psikomotrik. Pengembangan yang dilakukan melalui model permainan ini adalah keseimbangan.

\section{Analisis Data Permainan Berlari Memindahkan Bola dengan Shuttle Run}

Penilaian observasi ahli materi terhadap permainan rintangan ini menyatakan bahwa model ini termauk kategori sangat baik digunakan untuk latihan kebugaran jasmani anak usia 10-12 tahun baik ranah kognitif, afektif, maupun psikomotrik. Pengembangan yang dilakukan melalui model permainan ini adalah kelincahan.

\section{Analisis Data Permainan Lompat Satu Kaki Melewati Lingkaran}

Penilaian observasi ahli materi terhadap permainan rintangan ini menyatakan bahwa model ini termasuk kategori sangat baik digunakan untuk latihan kebugaran jasmani anak usia 10-12 tahun baik ranah kognitif, afektif, maupun psikomotrik. Pengembangan yang dilakukan melalui model permainan ini adalah kelincahan dan keseimbangan.

\section{Analisis Data Permainan Rintangan Pole Flying}

Penilaian observasi ahli materi terhadap permainan rintangan ini menyatakan bahwa 
model ini termauk kategori sangat baik digunakan untuk latihan kebugaran jasmani anak usia 10-12 tahun baik ranah kognitif, afektif, maupun psikomotrik. Pengembangan yang dilakukan melalui model permainan ini adalah keberanian, kecepatan mengambil keputusan, dan keseimbangan.

\section{Analisis Data Permainan Lari Balok}

Penilaian observasi ahli materi terhadap permainan lari rintangan lari balok menyatakan bahwa model ini termauk kategori sangat baik digunakan untuk latihan kebugaran jasmani anak usia 10-12 tahun baik ranah kognitif, afektif, maupun psikomotrik. Pengembangan yang dilakukan melalui model permainan ini adalah kecepatan reaksi, keseimbangan, kekuatan otot tungkai, dan keberanian.

\section{Analisis Data Permainan Mengumpulkan Cone dengan Warna yang Sesuai dengan Petunjuk yang Diterima.}

Penilaian observasi ahli materi terhadap permainan rintangan ini menyatakan bahwa model ini termasuk kategori sangat baik digunakan untuk latihan kebugaran jasmani anak usia 10-12 tahun baik ranah kognitif, afektif, maupun psikomotrik. Pengembangan yang dilakukan melalui model permainan ini adalah kecepatan reaksi, kecepatan mengambil keputusan, dan kerja keras pantang menyerah.

\section{Revisi Produk}

Berdasarkan analisis dari data yang diberikan oleh ahli materi, maka dilakukan revisi terhadap draf model permainan rintangan yang telah diujicobakan dalam skala besar sebagai berikut:

\section{Berguling Samping Dilanjutkan dengan Lari Lurus Sejauh 10 Meter}

Sasaran pemainannya yaitu, (1) Secara tidak sadar anak telah melaksanakan latihan kecepatan dan kelincahan (psikomotor); (2) Anak dapat mengambil keputusan dengan melalui proses berpikir cepat dan tepat (kognitif); (2) Anak memiliki jiwa kompetisi dan sportifitas yang tinggi (afektif).

Peralatan permainannya yaitu, (1) kapur sebagai garis batas mulai bergerak; (2) matras spon ukuran $1 \times 1 \mathrm{~m}$ atau sejenisnya dari bahan yang lunak dan aman.
Lapangan permainan

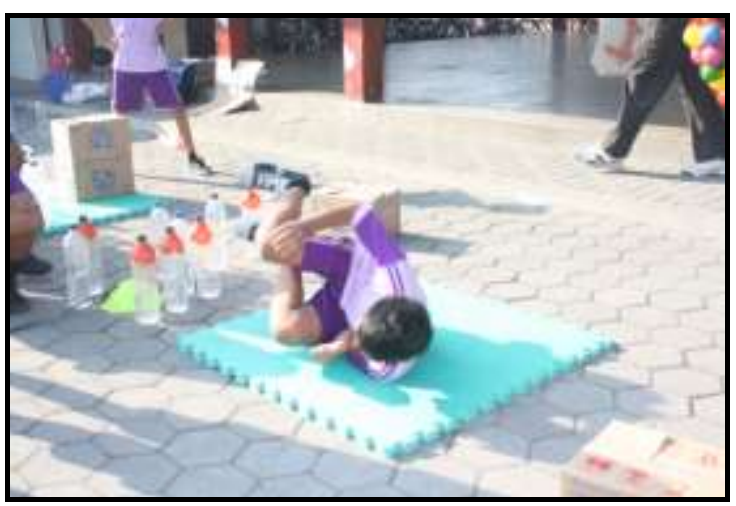

Gambar 1. Lintasan Lurus Sepanjang $\pm 12 \mathrm{~m}$, yaitu Lintasan yang Dibutuhkan 10 dan Safety

Zone $1 \mathrm{~m}$ di Awal dan di Akhir Lintasan

Prosedur pelaksanaan permainan, yaitu: dalam permainan ini anak bersiap di awal lintasan dan harus melewati rintangan berupa matras berukuran 1 x 1 meter dengan cara menggulingkan badan ke samping. Kemudian dilanjutkan dengan cepat berlari ke depan lurus.

Prosedur keselamatan dalam permainan ini yaitu: (1) Prosedur umum sebelum kegiatan adalah melakukan pemanasan yang cukup di awal dan pendinginan di akhir kegiatan; (2) Dalam melakukan guling ke samping bertumpu pada bahu dengan tetap mempertahankan keseimbangan agar dapat melanjutkan lari lurus ke depan.

\section{Lari Rintangan Kardus}

Sasaran permainannya yaitu: (1) Melatih komponen kebugaran jasmani kecepatan, kekuatan otot tungkai, kesimbangan, kelincahan, dan ketepatan pada sasaran (psikomotorik); (2) Anak melakukan proses berpikir dan mengambil keputusan dengan cepat pada saat bermain rintangan (kognitif); (3)Anak memiliki jiwa kompetisi dan sportifitas yang tinggi (afektif); (4) Anak dapat melaksanakan permainan ini dengan gembira sebagai wujud dari semangat yang besar dalam bermain; (5) Anak memiliki rasa percaya diri yang tinggi (afektif).

Peralatan permainannya antara lain: (1) kapur sebagai tanda; (2) kardus bekas ukuran $20 \mathrm{~cm}$ x $35 \mathrm{~cm}$ sebanyak 12 buah; (3) peluit 1 buah.

Lapangan permainan, yaitu: (1) Luas area kurang lebih $12 \mathrm{~m}^{2}$; (2) Tempat permainan diusahakan di tempat yang rata. 


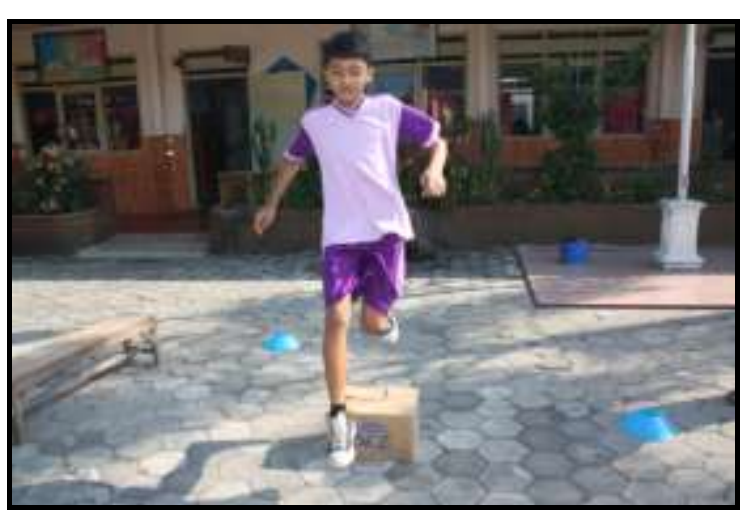

Gambar 2. Permainan Rintangan Kardus

Prosedur permainan yang dilakukan, yaitu: (1) Lintasan disiapkan sebanyak dua buah lintasan masing-masing terdiri dari 12 buah kardus yang disusun; (2) Sistem kompetisi dalam permainan rintangan ini dibuat dengan model berpasangan; (3) Diawal lintasan dibuat garis start dengan menggunakan kapur; (4) Setiap kelompok berdiri di garis start masingmasing; (5) Guru memberi aba-aba dengan peluit; (6) Setelah guru memberi aba-aba tanda dimulai, maka kedua kelompok berlomba untuk mencapai garis finish dengan cepat; (7) Anggota kelompok satu persatu berlari sesuai dengan aba-aba dari guru.

Prosedur keselamatan dalam permainan ini yaitu: (1) Tumpuan kaki pada saat menolak dan mendarat harus tepat pada posisi yang kuat; (2) Pada saat mendarat diusahakan lutut mengeper untuk meredam beban berat badan.

\section{Merobohkan Semua Cone yang Berada di Area Permainan}

Sasaran permainannya yaitu: (1) Secara tidak sadar anak telah melaksanakan latihan kecepatan reaksi dan kelincahan (psikomotor). (2) Anak dituntut untuk berpikir untuk menentukan cone mana yang terlebih dahulu dirobohkan. (kognitif). (3) Anak memiliki jiwa kompetisi dan sportifitas yang tinggi (afektif).

Peralatan permainan yang digunakan yaitu: (1) kapur putih atau tali rafia secukupnya; (2) cone modifikasi sebanyak 11 buah.
Lapangan Permainan

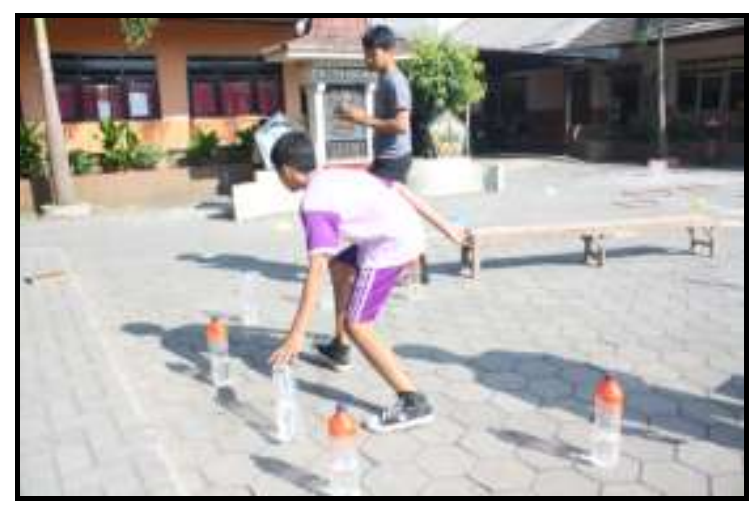

Gambar 3. Lapangan Seluas \pm 10 Meter

Prosedur permainan yang dilakukan yaitu: (1) Anak diminta untuk merobohkan semua cone yang telah ditata acak; (2) Dalam permainan ini dituntut kecepatan berpikir dan memutuskan cone mana yang akan dirobohkan terlebih dahulu sehingga bisa dengan cepat merobohkan semua cone yang ada.

Prosedur keselamatan dalam permainan ini yaitu: (1) Dibutuhkan tumpuan kaki yang kuat dan stabil dalam melakukan permainan ini; (2) Lakukan permainan ini di tempat yang cukup luas dan di tempat yang rata dan tidak licin.

\section{Lari Rintangan Cone Zig-Zag}

Sasaran permainannya, yaitu: (1) Melatih komponen kebugaran jasmani kelincahan melalui gerakan lari zig-zag dengan mengubah arah dengan cepat (psikomotorik). (2) Melatih kekuatan ekstremitas bawah yang secara otomatis terlatih dengan pemberian beban pada saat bergerak berlari zig-zag (psikomotorik). (3) Melatih keseimbangan kesimbangan melalui gerakan zig-zag yang dilakukan harus tetap stabil dan tidak sampai jatuh (psikomotorik). (4) Anak melakukan proses berpikir dan mengambil keputusan dengan cepat pada saat bermain rintangan (kognitif).

Peralatan permainan yang digunakan, yaitu: (1) cone yang dimodifikasi dengan memanfaatkan botol air mineral kapasitas $1500 \mathrm{ml}$ (mili liter); (2) kapur; (3) peluit 1 buah. 
Lapangan Permainan

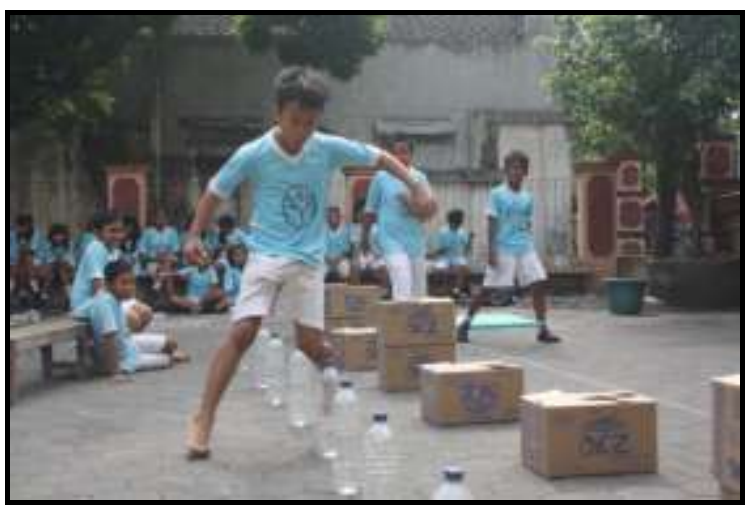

Gambar 4. Lapangan Permainan Rintangan Cone Zig-Zag

Prosedur permainan yang dilakukan, yaitu: (1) Lintasan yang disiapkan yaitu sebanyak dua buah lintasan masing-masing terdiri dari 10 cone modifikasi dari botol bekas air mineral; (2) Setiap anggota kelompok yang memasuki pos kedua ini langsung berlari zig-zag sesuai dengan pola yang telah diatur.

Tempat permainan yang dianjurkan, yaitu: (1) Tempat permainan ini dilaksanakan di lahan dengan luas kurang lebih $3 \mathrm{~m}^{2}$; (2) Tempat permainan diusahakan di tempat yang rata.

\section{Lari Rintangan Papan Titian}

Sasaran permainannya yaitu: (1) Melatih komponen kebugaran jasmani keseimbangan pada sasaran (psikomotorik). (2) Anak melakukan proses berpikir dan mengambil keputusan dengan cepat pada saat bermain rintangan (kognitif). (3) Melatih keberanian anak dan rasa percaya diri (afektif).

Peralatan permainan yang digunakan, yaitu: (1) papan titian dari kayu; (2) kapur.

\section{Lapangan Pemainan}

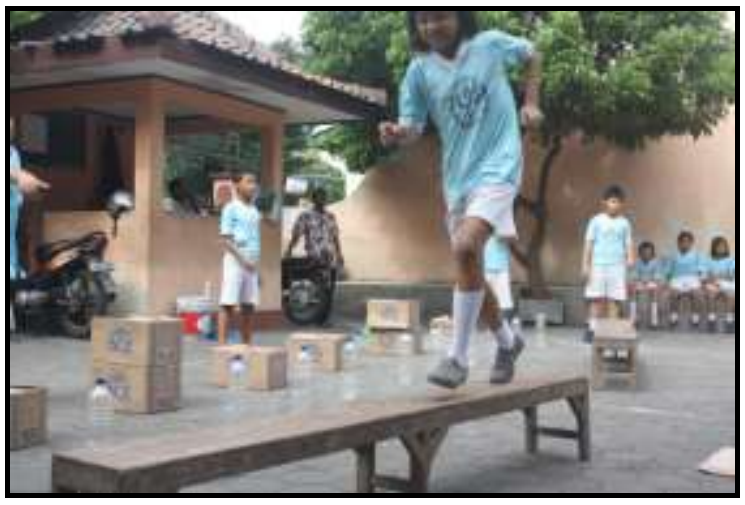

Gambar 5. Lapangan Berlari Melewati Rintangan Papan Titian

Prosedur permainannya adalah anak berlari cepat melewati rintangan papan kayu yang pertama kemudian turun, lalu anak tetap berlari dengan cepat kemudian melewati rintangan papan kayu yang kedua, dan dilanjutkan pada permainan berikutnya.

Prosedur keselamatan dalam permainan ini, yaitu: (1) Jaga keseimbangan saat berlari dan jangan sampai jatuh; (2) Pada saat naik dan turun papan kayu kaki harus menumpu dengan benar; (3) Papan kayu diusahakan dibuat statis.

\section{Walking on the Moon Menggunakan 5 Buah Papan dari Kardus}

Sasaran permainannya yaitu; (1) Melatih komponen kekuatan otot tungkai bawah (psikomotorik); (2) Anak dituntut untuk berpikir kreatif memecahkan masalah yang dihadapi, yaitu melewati lintasan berpola dengan tetap menginjakkan kaki pada papan kardus yang terbatas jumlahnya; (3) Membentuk karakter sosial, bekerja sama, mentaati peraturan, percaya diri, percaya pada orang lain, menghargai orang lain, toleransi, dan kerja keras (afektif).

Peralatan permainan yang digunakan yaitu: papan kardus bekas ukuran $50 \mathrm{~cm}^{2}$ dan kapur.

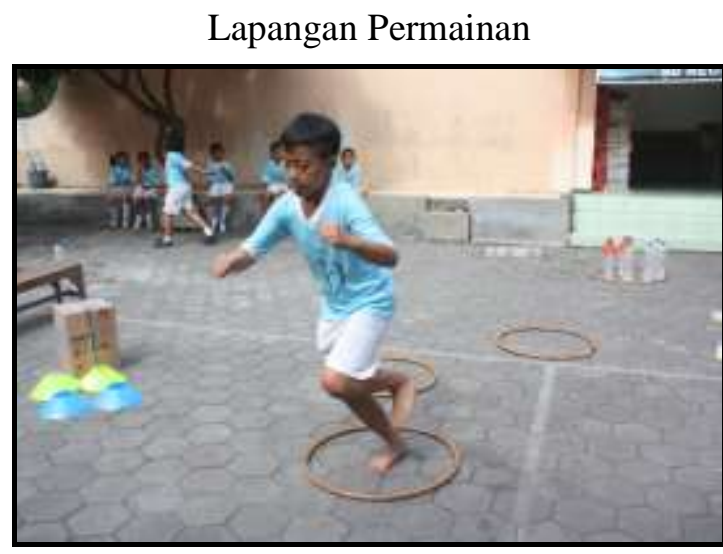

Gambar 6. Lapangan Walking on The Moon Menggunakan 5 Buah Papan dari Kardus

Prosedur permainannya yaitu: (1) Anak berjalan melewati lintasan yang telah dipersiapkan; (2) Setiap kali melangkah kaki harus selalu berada di atas papan; (3) Jaga keseimbangan agar tidak jatuh.

Keselamatan yang dihiharapkan adalah (1) menjaga kesimbangan agar tidak jatuh; (2) Kaki yang digunakan untuk melangkah harus menumpu kuat dan dalam posisi yang benar.

\section{Lari Melintasi Rintangan Tiang Pancang}

Sasaran permainannya yaitu: (1) Melatih komponen kelincahan; (2) Anak dituntut untuk berpikir dan memutuskan cara untuk 
melewati rintangan dengan berlari membentuk angka 8 (shuttle run) dengan membawa bola untuk dikumpulkan di tempat yang telah disediakan di ujung lintasan. Anak harus memilih warna bola yang boleh di bawa terlebih dahulu. Hal ini menuntut daya pikir, kejelian, dan konsentrasi untuk memecahkan permasalahan yang dihadapi (problem solving); (3) Membentuk karakter sosial, bekerja sama, mentaati peraturan, percaya diri, percaya pada orang lain, menghargai orang lain, toleransi, dan kerja keras.

Peralatan permainan yang digunakan adalah tiang pancang setinggi \pm 2 meter sebanyak 4 buah, tempat sampah plastik 2 buah, bola 8 buah dengan variasi 2 warna, dan peluit 1 buah.

\section{Lapangan Permainan}

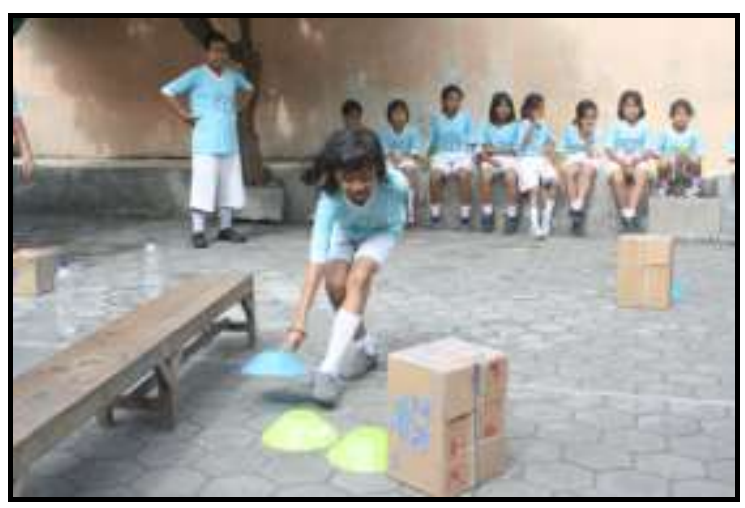

Gambar 7. Lapangan Lari Melintasi Rintangan Tiang Pancang

Prosedur permainan yang dilakukan yaitu: (1) Rintangan berupa dua tiang pancang setinggi \pm 2 meter yang dipasang dengan jarak 5 meter; (2) Diawal lintasan telah disediakan bola sebanyak 4 buah dengan variasi 2 warna; (3) Bola yang boleh di bawa untuk lari pertama dan kedua harus sama, demikian juga untuk lari ketiga dan keempat juga harus satu warna; (4) Berlari cepat membentuk angka delapan dengan melewati kedua rintangan tiang yang telah terpasang; (5) Setelah sampai diujung lintasan kemudian bola yang di bawa ditaruh di tempat yang telah disediakan; (6) Setelah itu anak kembali mengambil bola untuk dibawa lari dengan prosedur yang sama sampai bola yang keempat.

Keselamatan yang diharapkan yaitu: (1) Lakukan di tempat rata dan tidak licin; (2) Pada saat melakukan lari membentuk angka 8, maka tumpuan kaki saat belok dan merubah arah dengan tiba-tiba, posisi kaki harus stabil; (3) Jaga keseimbangan.
Lompat Satu Kaki (Engklek) Melewati Lingkaran Berpola

Sasaran permainannya yaitu: (1) Melatih komponen kekuatan otot tungkai bawah; (2) Anak dituntut untuk berpikir kreatif memecahkan masalah yang dihadapi, yaitu melewati lintasan berpola dengan lompat menggunakan satu kaki (engklek). Unsur ketepatan menempatkan pijakan kaki menjadi sangat penting dalam permainan ini; (3) Anak merasa terlibat dalam aktivitas kompetisi dalam kelompok sehingga mampu membentuk karakter sosial, bekerja sama, mentaati peraturan, percaya diri, percaya pada orang lain, menghargai orang lain, toleransi, dan kerja keras.

Peralatan permainan yang dipakai yaitu Simpai sebanyak 10 buah dan kapur putih, peluit 1 buah.

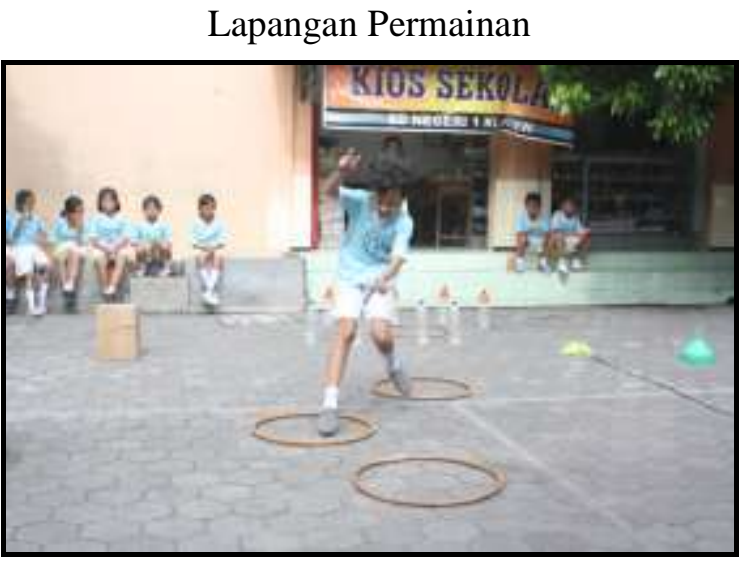

Gambar 8. Lapangan Lompat Satu Kaki (Engklek) Melewati Lingkaran Berpola

Prosedur permainan yang dilakukan yaitu: (1) Rintangan berupa jalur berpola menggunakan simpai dengan jarak $\pm 75 \mathrm{~cm}$ yang harus dilewati menggunakan dua buah papan kardus sampai dengan akhir; (2) Berjalan melewati lingkaran berpola yang dibuat dengan kapur putih dengan luas $\pm 1 \mathrm{~m}^{2}$, tiap kotaknya berjarak $\pm 75 \mathrm{~cm}$; (3) Peraturan dalam melewati lintasan ini adalah anak harus meLompat menggunakan satu kaki (engklek) dan menempatkan pijakan kaki pada lingkaran yang telah disediakan.

Prosedur keselamatan yang diharapkan yaitu: (1) Lakukan di tempat yang rata dan tidak licin; (2) Saat engklek pastikan posisi kaki tumpuan benar-benar siap; (3) Saat mendarat, kaki tumpu sedikit mengeper.

\section{Pole Flying}

Sasaran permainannya yaitu: (1) Melatih komponen kekuatan otot lengan dan bahu, 
ketepatan pada sasaran; (2) Anak dituntut untuk berpikir dan berkonsentrasi melompat bertumpu pada bambu dan berusaha mencapai sasaran yaitu lingkaran yang berjarak \pm 2 meter. Unsur ketepatan menempatkan pijakan kaki atau pendaratan menjadi sangat penting dalam permainan ini; (3) Anak dapat melaksanakan permainan ini dengan gembira sebagai wujud dari semangat yang besar dalam hal bermain. Semangat menjadi faktor yang sangat penting dalam mencapai keberhasilan latihan. Selain melaksanakan dengan semangat, anak juga tetap harus menjaga keseimbangan tubuhnya; (4) Anak merasa terlibat dalam aktivitas kompetisi dalam kelompok sehingga mampu membentuk karakter sosial, bekerja sama, mentaati peraturan, percaya diri, percaya pada orang lain, menghargai orang lain, toleransi, dan kerja keras.

Peralatan permainan yang dipakai adalah Simpai sebanyak 2 buah, kapur putih, tongkat bambu sepanjang $\pm 160 \mathrm{~cm}$ sebanyak 4 buah, dan peluit 1 buah.

\section{Lapangan Permainan}

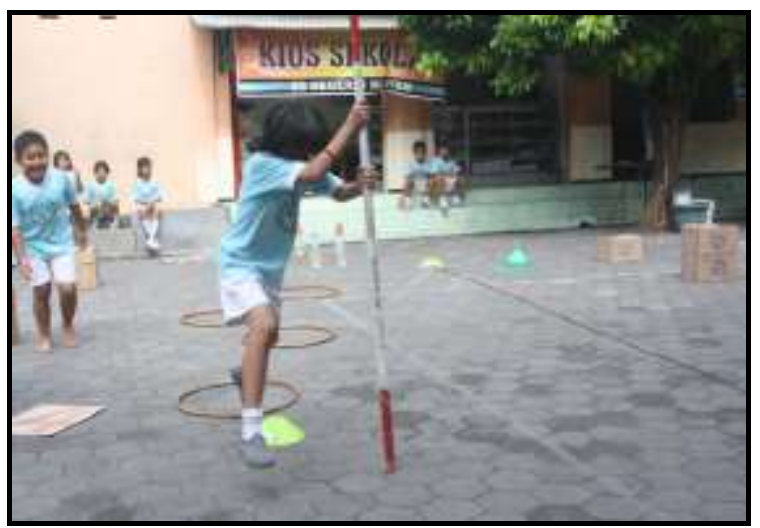

Gambar 9. Gambar Lapangan Permainan Pole Flying

Prosedur permainannya yaitu: (1) Rintangan berupa lintasan lurus yang berjarak \pm 2 meter yang harus dilewati dengan cara (pole flying) yaitu melompat bertumpu menggunakan tongkat bambu dan melakukan pendaratan pada daerah yang ditentukan; (2) Anak melewati rintangan yang berjarak \pm 2 meter dengan menggunakan tongkat dan melakukan pendaratan tepat pada sasaran, yaitu area lingkaran yang ditentukan; (3) Dalam permainan ini dituntut konsentrasi dan kesiapan fisik yang cukup. Rintangan ini sangat menantang bagi anak, sehingga mampu memberikan rangsangan yang kuat dan menyenangkan untuk bergerak dan berpikir kreatif.

Prosedur keselamatan yang diharapkan adalah (1) Lakukan di tempat yang rata dan tidak licin; (2) Pegangan tangan saat melakukan permainan ini harus kuat; (3) Saat mendarat kaki yang menumpu harus pada posisi yang tepat.

\section{Lari Balok}

Sasaran permainannya yaitu: (1) Melatih komponen kecepatan, kekuatan, dan kelincahan; (2) Anak dituntut untuk berpikir dan berkonsentrasi berjalan secepatnya dengan tetap berpijak pada papan sampai garis finish. (3) Anak merasa terlibat dalam aktivitas kompetisi dalam kelompok sehingga mampu membentuk karakter sosial, bekerja sama, mentaati peraturan, percaya diri, percaya pada orang lain, menghargai orang lain, toleransi, dan kerja keras.

Peralatan permainan yang digunakan adalah papan ukuran panjang $\pm 20 \mathrm{~cm}$, lebar \pm $10 \mathrm{~cm}$, dan tebal $\pm 5 \mathrm{~cm}$ dan kapur.

Lapangan Permainan

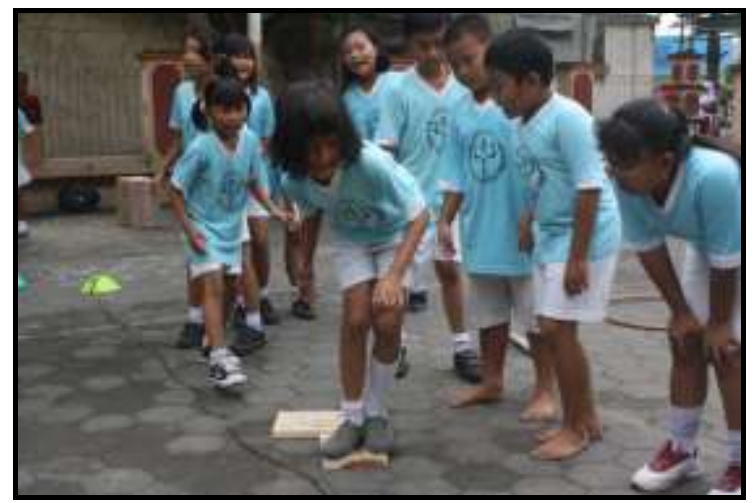

Gambar 10. Lapangan Lari Balok

Prosedur permainannya yaitu: (1) Rintangan berupa lintasan lurus yang berjarak \pm 8 meter yang harus dilewati dengan cara berjalan di atas papan kayu dengan secepat-cepatnya; (2) Anak melewati rintangan jarak sejauh \pm 8 meter dengan menggunakan balok kayu sebagai titian pijakan kaki. Upaya untuk menuju finish secepat-cepatnya menuntut anak untuk berjalan jongkok dalam setiap perpindahan tempat; (3) Dalam permainan ini dituntut konsentrasi dan kesiapan fisik yang cukup. Rintangan ini sangat menantang bagi anak, sehingga mampu memberikan rangsangan yang kuat dan menyenangkan untuk bergerak dan berpikir kreatif.

Prosedur untuk keselamatan yang diharapkan yaitu: (1) Lakukan di tempat yang rata dan tidak licin; (2) Tangan yang memindahkan papan harus hati-hati agar tidak terinjak; (3) Lakukan tumpuan kaki yang kuat. 
Mengumpulkan Semua Cone dengan Warna yang Sama Sesuai dengan Petunjuk yang Diterima

Sasaran permainannya yaitu: (1) Melatih komponen kecepatan reaksi (psikomotorik); (2) Anak dituntut untuk berpikir dan berkonsentrasi untuk melihat situasi sekitar dan memutuskan dengan cepat dan tepat dalam mengumpulkan cone menjadi satu di dalam lingkaran (kognitif); (3) Membentuk karakter sosial, bekerja sama, mentaati peraturan, percaya diri, percaya pada orang lain, menghargai orang lain, toleransi, dan kerja keras (afektif).

Peralatan permainan yang digunakan adalah cone sebanyak 8 buah dan kapur putih atau tali rafia secukupnya.

Lapangan Permainan

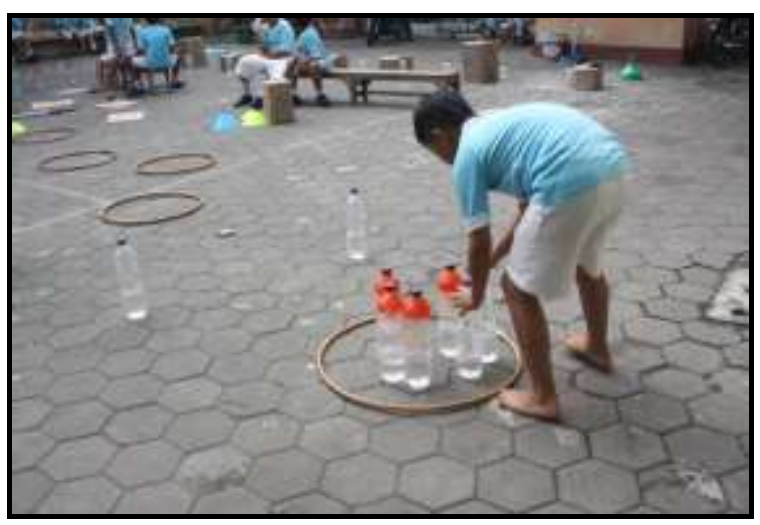

Gambar 11. Mengumpulkan Semua Cone dengan Warna yang Sama Sesuai dengan Petunjuk yang Diterima

Prosedur permainan yang dilakukan yaitu: (1) Anak diminta untuk mengumpulkan semua cone yang ada dalam area ini menjadi satu di tengah area di tempat yang telah disediakan; (2) Dalam permainan ini dituntut kecepatan berpikir dan memutuskan cone mana yang akan diambil terlebih dahulu sehingga didapatkan efektivitas gerakan.

Prosedur keselamatan yang diharapkan yaitu (1) Lakukan di tempat yang cukup luas dan terbuka; (2) Lakukan di tempat yang rata dan tidak licin; (3) Kaki tumpuan harus kuat.

\section{Simpulan dan Saran}

Simpulan

Hasil penilaian para ahli materi terhadap setiap variasi permainan model yang terkandung dalam permainan rintangan (handicap games) yang dikembangkan terdiri dari 11 variasi permainan, yaitu (1) guling samping dilanjutkan lari lurus 10 meter, (2) lari kardus, (3) roboh cone yang berada di dalam area, (4) lari zig-zag melewati cone, (5) lari melewati papan titian, (6) walking on the moon, (7) lari shuttle run membentuk angka delapan sejauh 5 meter, (8) lari engklek, (9) pole flying, (10) lari balok, dan (11) raup cone, dapat disimpulkan bahwa model latihan ini disusun sangat baik dan sangat efektif untuk latihan kebugaran jasmani anak usia 10-12 tahun. Oleh karena itu model latihan ini dapat disimpulkan layak untuk digunakan. Penggunaan permainan rintangan ini dilengkapi dengan buku petunjuk pelaksanaan permainan, sehingga lebih efektif dan mempermudah memahami permainan ini.

Saran

Peneliti menyarankan bahwa latihan ini diberikan kepada anak usia 10-12 tahun sehingga sesuai dengan karakteristik anak dan tahap tumbuh kembang anak.

Desiminasi hasil penelitian ini dibuat norma penilaian terhadap anak yang melakukan permainan ini sehingga guru mengetahui kebutuhan anak terhadap bentuk latihan kebugaran jasmani.

\section{Daftar Pustaka}

Andarmoyo, Sulistyo. (2011). Hubungan minat dan motivasi belajar dengan prestasi belajar mata kuliah anatomi fisiologi pada mahasiswa program studi D III Keperawatan, Fakultas Ilmu Kesehatan, Universitas Muhammadiyah Ponorogo. Tesis. Tidak dipublikasikan. Universitas Sebelas Maret Surakarta. Surakarta.

Borg, W. R. dan Gall, Meredith, Damien. (1983). Educational research: An introduction. $\left(4^{\text {th }} e d\right)$. New York: Longman Inc.

Branca, F \& Vatuena, S. (2001). Calcium, physical activity and bone health-building bones for a stronger future. Public Health Nutrition. 4, 117-123.

Depdiknas. (2003). Undang-undang RI Nomor 20, Tahun 2003, tentang Sistem Pendidikan Nasional.

Http://data.menkokesra.go.id (diambil pada 13 Maret 2013).

Iswana, Bayu. (2012). Model latihan keterampilan gerak pencak silat anak usia 9-12 
tahun. Tesis, tidak dipublikasikan. Universitas Negeri Yogyakarta.

Laxmi, Devi. (1998). Child development an introduction. New Delhi. Institut For Sustainable Development Lucknow \& Anmol Publications PVT. Ltd.

Nawawi \& Martini. (2006). Instrumen penelitian bidang sosial. Yogyakarta: Gadjah Mada University Press.
Yulianti, Nurma Ika. (2008). Hubungan antara minat dan prestasi belajar yang menyatakan bahwa semakin tinggi minat belajar maka semakin tinggi pula prestasi belajar yang dicapai. Tesis Magister. Tidak diterbitkan. Universitas Negeri Yogyakarta. Yogyakarta. 